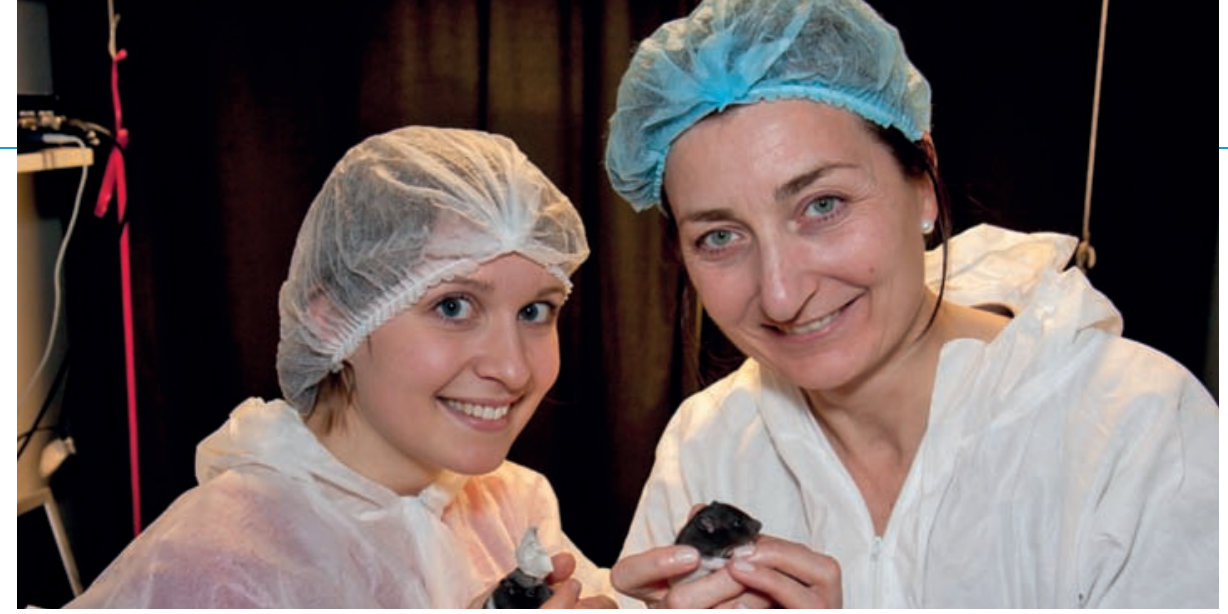

Tale Litleré Bjerknes (til venstre) og May-Britt Moser. Foto Raymond Skjerpeng

\section{Kartlegging av hjernens navigasjonssystemer}

\author{
Romlig representasjon har en medfødt komponent som er uavhengig \\ av erfaring, viser en ny norsk studie i Science med en forskerlinje- \\ student som forfatter.
}

Hippocampus og omkringliggende områder $i$ hjernen er viktige for hukommelse og for den kognitive representasjonen av omgivelsene rundt oss. I disse områdene er det hos rotter funnet spesialiserte celler som sender ut aksjonspotensialer når dyret er på ett bestemt sted i et miljø (plassceller). I tillegg er det identifisert retningsspesifikke celler (hoderetningsceller) og celler som aktiveres hver gang dyret passerer bestemte punkter $i$ et rutenett som dekker omgivelsene (gitterceller). Trolig er alle disse celletypene viktige for vår evne til å navigere.

- Vi brukte mikroelektroder til å gjøre opptak av elektrofysiologiske egenskaper hos enkeltceller i hippocampus og entorhinal cortex hos unge rotter som beveget seg fritt $i$ et definert miljø, sier forskerlinjestudent Tale Litleré Bjerknes i Trondheim, som er femteforfatter på artikkelen i Science (1).

- Det viste seg at allerede på det tidspunktet da dyrene åpnet $\varnothing y n e n e$ for første gang og begynte å orientere seg utenfor redet, dvs. ved 15-16 dagers alder, var både plassceller, hoderetningsceller og gitterceller til stede. Hoderetningscellene hadde helt like egenskaper og var til stede i samme antall som hos voksne dyr. Antallet plassceller og gitterceller var derimot lavere, og det tok noen dager før de elektrofysiologiske egenskapene var som hos voksne dyr. Plasscellene og gittercellenes stabilitet og spesifikke fyringsmønster var avhengig av alder, mens det ikke hadde sammenheng med hvor mange ganger de unge rottene hadde utforsket miljøet.

Selv om flere studier må til for nøyaktig å kartlegge hvilken rolle erfaring har for modningen av hjernens navigasjonssystemer, viser studien at essensielle komponenter for hjernens representasjon av omverdenen allerede er til stede når et dyr opplever et miljø for første gang. Dette st $\varnothing$ tter synet om at romlig representasjon har en medfødt komponent som er uavhengig av erfaring.

Funnene er interessante, særlig fordi filosofen Immanuel Kant allerede i 1781 mente at noen egenskaper ved kognisjon, såkalte a priori-egenskaper, ikke kunne komme fra erfaring, men måtte være medfødt. Kant mente bl.a. at kunnskap om rommet er til stede hos oss mennesker før vi har gjort oss noen erfaringer om det, sier Litleré Bjerknes.

\section{Forskning på hukommelse}

Kavli-instituttet og Senter for hukommelsesbiologi ved Norges teknisk-naturvitenskapelige universitet ledes av professorene May-Britt og Edvard Moser. Hovedinteressen er å forstå kognitive prosesser i nevrale nettverk. Dette gjøres ved å studere stedsans og spatial hukommelse for å avdekke generelle prinsipper for hvordan nevronale nettverk fungerer i hjernen hos pattedyr. Forskergruppen har bidratt vesentlig til forskningsfeltet med bl.a. oppdagelsen av gittercellen.

Denne studien ble utført av postdoktorene Rosamund Langston og James Ainge, mens forskerlinjestudent Tale Litleré Bjerknes bidro i de funksjonelle studiene av hoderetningsceller og gitterceller hos unge og voksne dyr. I tillegg bidro anatomigruppen ved senteret, ledet av professor Menno Witter, med å unders $\emptyset$ ke hvor modent nettverket av celler i de aktuelle områdene $i$ hjernen var ved ulike aldre in vitro.

\section{Erlend Hem}

erlend.hem@medisin.uio.no

Tidsskriftet

\section{Litteratur}

Litteratur
1. Langston RF, Ainge JA, Couey JJ et al. Development of the spatial representation system in the rat. Science 2010; 328: 1576-80.

\section{Ordforklaringer}

Plassceller: Celler i hippocampus som sender ut aksjonspotensialer akkurat når et dyr befinner seg på et spesifikt sted i et miljø, men ikke ellers.

\section{Hoderetningsceller (kompassceller):} Celler som ble oppdaget i dorsale presubiculum, og som senere også er beskrevet i entorhinal cortex, som sender ut aksjonspotensialer når et dyr har hodet i en bestemt retning i horisontalplanet.

Gitterceller (grid cells): Celler i entorhinal cortex som sender ut aksjonspotensialer i et periodisk heksagonalt mønster over hele miljøet et dyr befinner seg i.

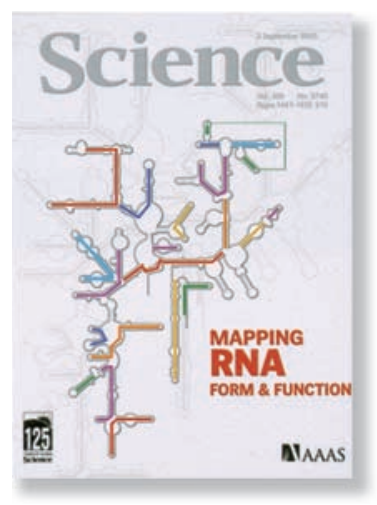

Artikkelen ble 18.6. 2010 publisert i det prestisjetunge tidsskriftet Science (www.sciencemag.org). Gjengitt med tillatelse. () 2006 AAAS 